УДК 340

DOI 10.18101/2658-4409-2019-4-32-37

\title{
АКТУАЛЬНЫЕ НАПРАВЛЕНИЯ ИССЛЕДОВАНИЙ ПРАВОВОЙ ИНТЕГРАЦИИ РЕГИОНОВ В ОБЩЕГОСУДАРСТВЕННУЮ ПРАВОВУЮ СИСТЕМУ
}

\author{
(C) Авдеева Ольга Анатольевна \\ доктор юридических наук, профессор, \\ Восточно-Сибирский институт МВД России \\ Россия, 664074, г. Иркутск, ул. Лермонтова, 110 \\ E-mail: avdeeva_o_a@mail.ru
}

Правовое регулирование принципов организации государственной власти предполагает регламентацию правового статуса субъектов, образующих состав государства. Государственно-правовое строительство в России отличалось политикой поэтапного интегрирования регионов в общеимперскую правовую систему. Правовая политика России в период империостроительства на территории Сибири проводилась с учетом геополитического, социально-экономического, демографического факторов, специфики стратификации населения, родоплеменной организации коренных народов.

Ключевые слова: империя; правовая политика; правовая интеграция; правовое регулирование; правовая система; правовой обычай.

\section{Для цитирования}

Авдеева O. А. Актуальные направления исследований правовой интеграции регионов в общегосударственную правовую систему // Вестник Бурятского государственного университета. Юриспруденция. 2019. Вып. 4. С. 32-37.

Анализ правового статуса субъектов, образующих состав Российского государства в XVII-XIX вв., в силу актуальности проблемы совершенствования механизма правового регулирования в условиях глобализации и интеграции международной жизни находится в поле пристального внимания научных кругов. Отдельные аспекты интеграции коренных народов в общегосударственную правовую систему получили отражение в работах Н. Н. Ефремовой, Л. Е. Лаптевой, С. В. Кодана, Л. А. Стешенко и др. ${ }^{1}$

\footnotetext{
${ }^{1}$ Ефремова Н. Н. Судоустройство России в XVIII - первой половине XIX вв. (историко-правовое исследование). М., 1993; Лаптева Л. Е. Региональное и местное управление в России (вторая половина ХІХ в.). М., 1998; Кодан С. В. Юриди-
} 
O. А. Авдеева. Актуальные направления исследований правовой интеграции регионов в общегосударственную правовую систему

Исследуя процесс реформирования государственного аппарата в контексте взаимодействия государственных органов исполнительной и судебной власти, Л. Е. Лаптева промульгирует идею о «традиционной особенности политики Российской империи в отношении нерусских народов», обусловившую наличие в механизме реализации публичной власти признаков национальной автономии. В развитие данного подхода С. В. Кодан отмечает особенности процесса империостроительства в России, связанные с отсутствием по сравнению с колониальными государствами «резко очерченного деления на метрополию и колонии». Л. А. Стешенко подчеркивает, что «генеральным направлением» в механизме правового регулирования статуса туземных народов являлось проведение «прагматичной, гибкой политики».

Ввиду актуальности проблема правового статуса субъектов, образующих состав государства в период империостроительства, нашла отражение в работах зарубежных и отечественных политологов. Так, немецкий ученый Андреас Каппелер отметил создание по сравнению с «западной американской экспансией» на окраинах Российской империи «более человечной модели контактов между европейцами и неевропейскими охотниками и кочевниками» ${ }^{1}$. В свою очередь, российский политолог С. И. Каспэ обозначил особенности государственно-правового строительства в России, сопряженные с функционированием государственного аппарата исходя из этнополитической и этнокультурной специфики народов, населяющих окраины государства. По мнению С. И. Каспэ, в правовой политике Российской империи наличествовали «рациональные мотивы», обусловившие заселение «экономически ценных» и «безлюдных земель» и внедрение методов и средств реализации государственной власти, содействующих предотвращению состояния «опасности внешней агрессии» ${ }^{2}$.

Принимая во внимание многоаспектность подходов к проблеме правового статуса субъектов Российского государства, стоит отметить, что Россия в период империостроительства представляла собой сложное государственное образование. Расширение территориальных границ предопределяло необходимость законодательного регулирования региональных принципов формирования и реализации публично-властных отноше-

ческая политика Российского государства в 1800-1850-е гг.: деятели, идеи, институты. Екатеринбург, 2005; Стешенко Л. А. Многонациональная Россия: государственно-правовое развитие. X-XXI вв. М., 2002.

${ }^{1}$ Капеллер А. Э. Россия - многонациональная империя. М., 2000. С. 35.

${ }^{2}$ Каспэ С. И. Империя и модернизация: общая модель и российская специфика. M., 2001. C. 114. 
ний. Так, при разработке правовой политики в отношении Сибири главенствующее значение имела стратегическая роль данного региона в решении задач по обеспечению внешней безопасности и территориальной целостности ввиду наличия «пустующих пограничных земель» и стремления колониальных стран Западной Европы по колонизации «сибирского пространства».

Государственно-правовое строительство на территории Сибири отличалось политикой поэтапного интегрирования региона в общеимперскую правовую систему. Правовая политика России проводилась с учетом геополитического, социально-экономического, демографического факторов, основываясь на особенностях родоплеменной организации коренных народов Сибири и их этнической раздробленности. Специфика территориальной организации власти на территории Сибири заключалась в установлении в рамках унитарного государственного устройства «особых» принципов формирования органов государственной власти и самоуправления и реализации ими публично-властных полномочий.

С одной стороны, наметилась политика по целенаправленной централизации управления посредством учреждения Сибирского приказа, координирующего реализацию на востоке страны вверенных полномочий в сфере осуществления исполнительной и судебной власти. В обоснование данных принципов реализации государственной власти легла отдаленность Сибири от «имперского центра» и ее территориальная протяженность. В результате по мере поэтапного освоения проводится политика военного администрирования, предусматривающая: создание разрядов и воеводств; учреждение в 1708 г. в целях дальнейшей централизации управления Сибирской губернии; разукрупнение ввиду расширения территориальных границ Сибирской губернии на Тобольское и Иркутское генерал-губернаторства; разделение Сибири в 1822 г. на ЗападноСибирское и Восточно-Сибирское генерал-губернаторства. В ходе реализации во второй половине XIX - начале XX в. с учетом геополитического фактора политики военного администрирования: Западно-Сибирское генерал-губернаторство было упразднено; создано Степное генералгубернаторства; в качестве самостоятельных административнотерриториальных единиц выделены Тобольская и Томская губернии; Восточно-Сибирское генерал-губернаторство преобразовано в Иркутское генерал-губернаторство в составе Енисейской и Иркутской губерний, Якутской и Забайкальской областей; на территории Дальнего Востока путем отделения от Восточной Сибири учреждено Приамурское генерал- 
O. А. Авдеева. Актуальные направления исследований правовой интеграции регионов в общегосударственную правовую систему

губернаторство в составе Приморской, Амурской, Камчатской и Сахалинской областей.

Таким образом, реализация государственной политики в период империостроительства характеризуется созданием на территории Западной и Восточной Сибири, Дальнего Востока административно-территориальных единиц, наделяемых разным правовым статусом во взаимодействии с центральными органами государственной власти.

Политика военного администрирования предопределила особенности структуризации и функционализации органов государственной власти. В частности, принимая во внимание такие факторы, как активизация деятельности по освоению территории, мобильность русскоязычных переселенцев, миграционные процессы инородческого населения, концентрация сосланных на каторгу и поселение, предопределившие актуализацию проблемы удержания власти на новозавоеванной территории, в условиях острого дефицита кадрового потенциала и недостатка лиц дворянского происхождения проводится политика по предоставлению органам местной администрации судебной власти.

С другой стороны, ввиду экономического потенциала региона и реализации налоговой политики, «неравномерности распределения населения, его разбросанности и происходящей отсюда значительности расстояний между поселениями» осуществляется активная деятельность по изучению «условий применения» общеимперского законодательства, производится «запрос мнений и заключений» глав сибирской администрации о состоянии «общественно-экономических отношений» и «местных торгово-промышленных и сельскохозяйственных интересов». Особенностью реализации публично-властных отношений в Сибири является роль институтов общественного управления, действующих по территориальному, сословному и корпоративному принципам. В процессе освоения Сибири на основании Сибирского учреждения 1822 г. создается разветвленная система волостных, горных, станичных, крестьянских, духовных, городских органов общественного управления. Для обеспечения стабильности и правопорядка на законодательном уровне регламентируются «предметы и пределы власти» органов общественного управления. Особое внимание уделялось созданию на территории Сибири эффективной системы самоуправления коренных народов. В соответствии с Уставом об управлении инородцев 1822 г. и Положением об инородцах 1892 г. организация «поразрядного» инородческого управления предусматривала переход от «прямого» к «косвенному» управлению, осуществлявшемуся на основе исторически сложившихся «изустных правил». 
Деятельность органов общественного управления содействовала реализации государственной политики в сфере обеспечения паспортного режима, выполнения местным населением ясачной и рекрутской повинности, противопожарных мер, а также разрешению судебных дел, возбуждаемых по «торговым спорам, питейным сборам, взысканию казенных недоимок, обидам, ссорам, дракам и прочим запрещенным законами поступкам» ${ }^{1}$.

Резюмируя вышеизложенное, можно заключить, что государственноправовая политика России в отношении Сибири в период империостроительства с учетом военно-стратегических задач государства, геополитических, этнических, демографических факторов, влекущих специфику развития региона, отличалась активной правотворческой деятельностью, направленной на оптимизацию административных и иных ресурсов, содействовавших поэтапному интегрированию региона в общеимперскую правовую систему.

\section{Литература}

1. Кодан С. В. Империя как политико-правовое явление (теоретический и исторический аспекты) // Государство и право в условиях глобализации: проблемы и перспективы. Екатеринбург, 2004. С. 94-98.

2. Лаптева Л. Е. Опыт типологии административной политики // Право и политика. 2001. № 8. С. 58-64.

3. Хаген Марк, фон. История России как история империи: перспективы федералистского подхода // Российская империя в зарубежной историографии. М.: Новое издательство, 2005. С. 18-47.

4. М. М. Сперанский: Сибирский вариант имперского регионализма (к 180-летию сибирских реформ М. М. Сперанского) / Л. М. Дамешек [и др.]. Иркутск: Оттиск, 2003. 264 с.

5. Мигунова Т. Л. Правовой аспект общинного самоуправления в период правления Екатерины II // История государства и права. 2004. № 4. C. $55-58$.

${ }^{1}$ ГАИО. Ф. 9. Оп. 1. Д. 286, 360; Ф. 435. Оп. 1. Д. 97, 106. 
O. А. Авдеева. Актуальные направления исследований правовой интеграции регионов в общегосударственную правовую систему

\section{ACTUAL DIRECTIONS OF RESEARCH LEGAL INTEGRATION \\ OF REGIONS IN THE GENERAL LEGAL SYSTEM}

Olga A. Avdeeva

Doctor of Law, Professor,

East Siberian Institute of the Ministry of Internal Affairs of Russia

110 Lermontova str., Irkutsk 664074, Russia

E-mail: avdeeva_o_a@mail.ru

The legal regulation of the principles of the organization of state power presupposes the regulation of the legal status of entities forming the composition of the state. State-legal construction in Russia was distinguished by a policy of step-by-step integration of regions into the general imperial legal system. The legal policy of Russia during the period of empire-building in Siberia was carried out taking into account geopolitical, socioeconomic, demographic factors, specific stratification of the population, tribal organization of indigenous peoples.

Keywords: empire; legal policy; legal integration; legal regulation; legal system; legal custom. 